\title{
Perceived Influence of Core Values to the Behaviors of Senior High School Students
}

\author{
Joebel G. Imperial \\ University of Negros Occidental-Recoletos Bacolod City, Philippines \\ joebelimperial@gmail.com \\ https://orcid.org/0000-0003-0074-3202
}

\begin{abstract}
The school core values influence the desirable behaviors, beliefs, and attitudes of senior high school students. This descriptive-comparative study assessed the perceived degree of influence of the school core values on the behaviors of the senior high school students as assessed by students themselves and teachers. Using a researcher-made survey questionnaire, the data were collected and were analyzed using mean and Mann Whitney. The findings generally revealed that teachers and students strongly agree on the perceived influence of core values on students' behaviors. When results were compared according to assessors' designation, students significantly rated higher than teachers. On the other hand, students' assessment of the perceived influence of core values to students' behaviors showed a significant difference when compared according to sex, but no significant difference in the school of origin. The findings may be used as a basis for the formulation of a learning log in teaching Understanding Culture, Society, and Politics.
\end{abstract}

Keywords: Core Values, Perceived Influence, Behaviors, Senior High School Students, Bacolod City, Philippines 